\title{
Legal support for the use of natural therapeutic resources in sanatorium and resort treatment of the population
}

\author{
V. V. Kostytsky*1,A-F, V. D. Sydor ${ }^{2, A-F}$, I. O. Kostytska ${ }^{3, A-F}$
}

${ }^{1}$ Taras Shevchenko National University of Kyiv, Ukraine, ${ }^{2}$ Kyiv Institute of Intellectual Property and Law, National University “Odesa Law Academy", Institute of Legislation of the Verkhovna Rada of Ukraine, Kyiv

A - research concept and design; B - collection and/or assembly of data; C - data analysis and interpretation; D - writing the article; $\mathrm{E}$ - critical revision of the article; $\mathrm{F}$ - final approval of the article

Key words: natural therapeutic resources, heals resort, mineral water, medical mud, climate, treatment, medical rehabilitation, prevention.

\section{Zaporozhye}

medical journal

2019; 21 (6), 802-807

DOl:

10.14739/2310-1210

2019.6.186603

*E-mail:

v.kostytsky@yahoo.com
The aim. To conduct a comprehensive study of the legal regulation peculiarities of natural therapeutic resources and factors of sanatorium and resort treatment for the population, to identify problems of legal regulation of these relations and to outline the ways to resolve them.

Materials and methods. The research material is a modern regulatory framework. The methods of information retrieval, analysis, systematization and generalization were carried out.

Results. It has been established that natural therapeutic resources include mineral and thermal water, medical mud and ozokerite, sea and lake brine, sea water, natural objects and complexes with favorable climatic conditions. It has been substantiated that sanatorium and spa treatment is an important part that provides continuity and complexity of medical rehabilitation measures. The main resorts, located on the territory of Ukraine, have been described. It has been determined that regulation of social relations in the sphere of organization and development of resorts and sanatorium-resort treatment, detection and accounting of natural medical resources, ensuring their rational extraction, use and protection in order to create favorable conditions for treatment, medical rehabilitation, prevention of diseases and vacation for people is provided by environmental, land, health care and resort legislation.

Conclusions. Legal regulation of the natural therapeutic resources usage is ensured by environmental, land, health care and resort legislation. The purpose of this legislation is to regulate social relations in the sphere of organization and development of resorts and sanatorium and spa treatment, to detect and account natural medical resources, to ensure their rational extraction, use and protection in order to create favorable conditions for treatment, medical rehabilitation, prevention of diseases and population health improvement.

Efficient exploitation of natural therapeutic resources in resort treatment is currently affected by a number of economic, political, environmental problems, which have to be solved by organizational and legal means of the state impact on such legal relations.
Киючові слова: природні ресурси, санаторій, мінеральні води, лікувальні грязі, киімат, мікування, медична реабімітація, профілактика.

Запорізький медичний журнал. - 2019. -

T. 21, № 6(117), C. 802-807

\section{Правове забезпечення використання природних мікувальних ресурсів у санаторно-курортному мікуванні населення}

\section{В. В. Костицький, В. А. Сидор, І. О. Костицька}

Мета роботи - здійснити всебічне вивчення особливостей правового регулювання природних лікувальних ресурсів, факторів санаторно-курортного лікування населення, виявити проблеми правового регулювання означених правовідносин та окреслити шляхи їхнього вирішення.

Матеріали та методи. Матеріал дослідження - сучасна нормативно-правова база. Використані методи інформаційного пошуку, аналізу, систематизації та узагальнення.

Результати. Встановили, що до природних лікувальних ресурсів належать мінеральні й термальні води, лікувальні грязі та озокерит, ропа лиманів та озер, морська вода, природні об'єкти, комплекси зі сприятливими для лікування кліматичними умовами. Обґрунтували, що санаторно-курортне лікування - важлива частина, що забезпечує безперервність, наступність і комплексність лікувальних реабілітаційних заходів.

Схарактеризовано основні курорти, котрі розміщені на території України. Визначено, що регулювання суспільних відносин у сфері організації, розвитку курортів і санаторно-курортного лікування, виявлення та обліку природних лікувальних ресурсів, забезпечення їх раціонального видобутку, використання та охорони з метою створення сприятливих умов для лікування, медичної реабілітації, профілактики захворювань та відпочинку людей забезпечується екологічним, земельним законодавством, законодавством про охорону здоров'я та про курорти.

Висновки. Правове регулювання використання природних лікувальних ресурсів забезпечується екологічним, земельним законодавством, охороною здоров'я та курортів. Метою цього законодавства є регулювання суспільних відносин у сфері організації та розвитку курортів і санаторно-курортного лікування, виявлення, облік природних медичних ресурсів, забезпечення їхнього раціонального видобутку, використання та охорони з метою створення сприятливих умов для лікування, медичної реабілітації, профрілактики захворювань та оздоровлення людей.

Ефективне використання природних лікувальних ресурсів у санаторно-курортному лікуванні населення нині має низку серйозних проблем економічного, політичного, екологічного характеру, що мають бути вирішені за допомогою організаційно-правових заходів державного впливу на зазначені правовідносини. 


\section{Правовое обеспечение использования природных кечебных ресурсов в санаторно-курортном лечении населения}

\section{В. В. Костицкий, В.А. Сидор, И. А. Костицкая}

Цель работы - провести всестороннее изучение особенностей правового регулирования природных лечебных ресурсов и фракторов санаторно-курортного лечения населения, выявить проблемы правового регулирования этих правоотношений и очертить пути их решения.

Материалы и методы. Материал исследования - современная нормативно-правовая база. Использованы методы информационного поиска, анализа, систематизации и обобщения.

Результаты. Установлено, что к природным лечебным ресурсам относятся минеральные и термальные воды, лечебные грязи, озокерит, рапа лиманов и озер, морская вода, природные объекты и комплексы с благоприятными для лечения климатическими условиями. Обосновано, что санаторно-курортное лечение является важной частью, обеспечивает непрерывность, преемственность и комплексность лечебных реабилитационных мероприятий. Охарактеризованы основные курорты, расположенные на территории Украины. Определено, что регулирование общественных отношений в сфере организации и развития курортов и санаторно-курортного лечения, выявления и учета природных лечебных ресурсов, обеспечение их рациональной добычи, использования и охраны с целью создания благоприятных условий для лечения, медицинской реабилитации, профрилактики заболеваний и отдыха людей обеспечивается экологическим, земельным законодательством, законодательством об охране здоровья и о курортах.

Выводы. Правовое регулирование использования природных лечебных ресурсов обеспечивается экологическим, земельным законодательством, охраной здоровья и курортов. Целью этого законодательства является регулирование общественных отношений в сфере организации и развития курортов и санаторно-курортного лечения, выявление и учет природных медицинских ресурсов, обеспечение их рациональной добычи, использования и охраны с целью создания благоприятных условий для лечения, медицинской реабилитации, профилактики заболеваний и оздоровления людей.

Эффективное использование природных лечебных ресурсов в санаторно-курортном лечении населения в настоящее время имеет ряд серьезных проблем экономического, политического, экологического характера, которые должны быть решены с помощью организационно-правовых мер государственного воздействия на указанные правоотношения.

The relevance of the chosen topic of the research has been stipulated by the provisions of Art. 3 of the Constitution of Ukraine, which declared that "An individual, his life and health, honor and dignity, inviolability and security shall be recognized in Ukraine as the highest social value". Also Art. 49 of the Basic Law lays down that "Everyone shall have the right to health protection, medical care and medical insurance. Health protection should be ensured through state funding of the relevant socio-economic, medical and sanitary, health improvement and prevention programs" [1]. It is an important fact that the legislator defines health as "a state of complete physical, mental and social well-being and not only the absence of illness and physical disabilities (Art. 3 of the Fundamentals of Ukrainian Health Law)" [2]. It is worth recognizing that sanatorium and spa treatment is an important part that provides continuity and complexity of medical rehabilitation measures. This type of treatment and rehabilitation is necessary both for persons with chronic diseases and postoperative patients.

The immutability of natural therapeutic resources in the treatment of population, medical rehabilitation and diseases prevention as well as their legal bases were investigated at the dissertation level by such researches as A. Bobkova, A. Orlov, Yu. Petlyuk, V. Polyakov, O. Tkachenko and other Ukrainian scientists. However, a number of theoretical issues regarding the use of natural therapeutic resources and factors in the spa treatment of the population need further study.

\section{The aim}

To conduct a comprehensive study of the legal regulation peculiarities of natural therapeutic resources and factors of sanatorium and resort treatment for the population, to identify problems of legal regulation of these relations and to outline the ways to resolve them.

\section{Materials and methods}

The research material is a modern regulatory framework. The methods of information retrieval, analysis, systematization and generalization were carried out.

\section{Results}

The territory of Ukraine is characterized by exceptionally favorable natural and climatic conditions, as well as various resources availability for the treatment of the population. Scientific and technological progress stimulates the continuous improvement of methods of prevention, diagnosis, treatment and rehabilitation.

Almost everything has changed during the last century, but the main point has remained unchanged - the maximum usage of natural therapeutic resources and factors in organizing the process of health improvement for patients. The Law of Ukraine "On Resorts" (Art. 6) refers to mineral and thermal waters, medical mud and ozokerite, sea and lake brine, sea water, natural objects and complexes with favorable climatic conditions suitable for use in treatment, medical rehabilitation and disease prevention [3].

All natural therapeutic resources are divided into:

- especially valuable and unique natural medical resources that can rarely be found on the territory of Ukraine, they have limited distribution or small reserves in the fields and are particularly favorable and effective for use in medical treatment, medical rehabilitation and disease prevention;
Киючевые слова: природные ресурсы, санаторий, минеральные воды, лечебные грязи, климат, мечение, медицинская реабилитация, профикактика.

Запорожский медицинский журнал. - 2019. T. 21, № 6(117). C. 802-807 
- common natural medical resources that can be found in different regions of Ukraine, they have significant reserves and are suitable for use in treatment, medical rehabilitation and prevention of diseases.

Areas with pronounced natural therapeutic factors: mineral springs, climatic and other conditions favorable for the treatment and rehabilitation of people are recognized as spa and health-improving zones (Art. 62 of the Law "On Environmental Protection") [4].

Resort is an exploited natural territory on the lands of health-improving purposes, which has natural medical resources, buildings and structures with the objects of infrastructure necessary for their exploitation, can be used for the purpose of treatment, medical rehabilitation, prevention of diseases and for recreation and subjected to special protection (Art. 1 Law of Ukraine "On Resorts") [3].

Occupying $0.01 \%$ of the territory of Ukraine (about 8.6 thousand hectares), the land of health-improving purposes plays an extremely important role as a natural resource with natural healing properties. The natural therapeutic properties of such lands are the availability of natural therapeutic resources within them, which are extremely effective means for the prevention and treatment, as a rule, of widespread human diseases [5].

There are all types of resorts on the territory of Ukraine: balneological, mud, climatic and various combinations: balneo-mud, climatic-balneological and climatic-mud. Medical profile (specialization) of resorts is determined taking into account the properties of natural medical resources. According to its specialization, resorts are divided into general-purpose resorts and specialized resorts for the specific diseases treatment. The Ministry of Health Care (Art. 5 of the Law of Ukraine "On Resorts") establishes medical profile of resorts [3].

The unique sources of mineral water are the main therapeutic factor in balneological resorts of Ukraine. The mineral waters are unevenly distributed. The largest number of sources is located in the Ukrainian Carpathians: Lviv, Ivano-Frankivsk, Chernivtsi and the Transcarpathian region [6]. More than 12 large deposits of radon water were discovered in the zone of the so-called Ukrainian crystalline shield, a granite platform that crosses Ukraine from the Northwest to the Southeast and covers the Rivne, Zhytomyr, Vinnytsia, Khmelnytskyi, Kyiv and, partially, Cherkasy, Kirovohrad, and Dnipropetrovsk regions.

Mineral water of various compositions is in the Donetsk, Poltava, Kharkiv, Luhansk, Kherson, Odesa, Zaporizhzhia regions and in the Crimea, where thermal water was first obtained during deep drilling (Saky, Moinake, Yevpatoriia).

The most popular resorts in Ukraine are Truskavets, Morshyn, Shklo (the Lviv region), Myrhorod (the Poltava region), Berezovsky mineral water of the Kharkiv region, as well as Poliana, Soiy, Shaian (the Transcarpathian region). Resorts of Nemirov and Liuben-Velyky in the Lviv region, Cherche in the Ivano-Frankivsk and Syniak in the Transcarpathia region have sources of sulfur-hydrogen water in combination with peat and ozokerite deposits.

Mineral water of the balneological resorts is used for the treatment of gastrointestinal tract, cardiovascular, nervous, respiratory, musculoskeletal system diseases, urological and gynecological diseases, skin diseases, metabolic disorders, occupational diseases, as well as for the health of pregnant women and children. If joint disease is to be treated, spa therapy should include the use of mineral water both for drinking and bathing.

The main healing factor in balneological resorts is mineral water intake. It produces a unique tonic and curative effect on the human body. Such water has a special composition with a unique combination of minerals and other useful nutrients. Following the indications and dosage, serious illness can be cured and quality of life can be improved. Drinking mineral water, taking healing baths and medical mud is a complex of balneological procedures that relieves fatigue, removes waste and toxins from the body, rejuvenates the skin, and normalizes pressure.

Truskavets is the famous balneological resort of Ukraine. The main treasure of Truskavets is the weakly mineralized hydrocarbonate-calcium-magnesium "Naftusia". Oil-derived substances add a specific flavor to the water as oil has long been extracted in this area. In total, there are 25 sources in the Truskavetsk region of which 14 are used with 10 varieties of water compositions. There are 2 pump-rooms in the city [7]. Treatment with mineral water is supplemented by ozokerite procedures.

The Skhidnytsia Balneological Resort is known far beyond Ukraine with its unique mineral water, which has no analogues in Europe. Mineral water Shidnytska "Naftusia" has 38 sources, 17 wells, more than 25 sources that have not been explored yet [8].

Balneological resort Morshyn provides integrated treatment of healing water from three sources, mineral coniferous and iodine-bromine baths and mud. The miraculous properties have given the Morshyn water its name "God's Mother", similar to the sanctified Jordanian water. In Morshyn, digestive system, urinary tract, gynecological diseases, metabolic and nervous disorders are treated [9]

The basis of treatment at the resort of Poliana (Svaliava) is the well-known medicinal table waters "Poliana Kvasova" and "Poliana Kupel". Waters of the Polyana are characterized by a high concentration of minerals and carbon dioxide and a specific taste. The main specialty of Poliana sanatoriums is the digestive organs treatment. Here, without the use of medicines, peptic ulcer disease, gastritis, erosions in remission are treated [10].

Kvasy is incredibly rich in mineral springs with over 80 of them. Local water belongs to the Essentuki type of water, it has been used for treatment since the middle of the XIX century when the first hydrotherapy hospital was opened in the village. According to the chemical composition, Kvasy water is distinguished by the presence of calcium, silicon-iron, hydrocarbon-sodium and hydrogen sulfide. In addition, mineral baths are used for the treatment of various diseases. The resort is specialized in the treatment of musculoskeletal and nervous system diseases [11].

The inalienable basis of treatment at the Shaian resort remains the healing hydrocarbon-sodium-silicon water "Shaianska". Two varieties of local waters "Shaianska-242" and "Shaianska-4" are characterized by high calcium, magnesium and iron content. The medicinal properties of Shaianska water are close to the known water types "Borjomi" and "Vishy-Seleston". Shaian water is prescribed for the treatment of chronic gastritis and peptic ulcer, gall bladder and urinary tract diseases, diabetes mellitus, etc. [12]. 
Bathing in Siniatska mineral water with admixture of hydrogen sulfide is prescribed for musculoskeletal, nervous system and skin diseases, etc [13].

The most famous mineral springs of the Mizhhiria region are Soimivske, Kelechinske, Vuchkivske, Kolochavske and Verkhniostrianske. Soimi resort has been known since the XVIII century. Chloride-hydrocarbonate water of the Soiminsky deposit, saturated with calcium, iron, zinc, manganese, is indicated for the prevention and treatment of digestive system diseases, diabetes mellitus, calcium deficiency, etc. Local water has a beneficial effect on the child's body development. Kolochava village is famous for the largest reserves of mineral water in the Transcarpathia, analogue to which is found only in Kamchatka. Lowmineralized chloride-hydrocarbonate-calcium-magnesium water supplies the body with the necessary micronutrients, eliminates toxins, stimulates the acid-forming function of the stomach. The uppermost layer of mineral water has 3 sources. The source number 3 on the site "Kvass" is characterized by special therapeutic properties. Its carbonic iron and manganese containing water is hydrocarbonate-sodium and -calcium chloride and is effective in the treatment for digestive system diseases [14].

The main therapeutic factors of the resort Myrhorod are peat mud and unique mineral water, which is not inferior to the Baden-Baden and Aachen waters [15].

Khmilnyk resort is unique with special radon water, as well as local peat mud. These are the main factors on which sanatorium and spa treatment is based. In addition, Khmilnyk resort is located in the picturesque area of the forest park, close to the Southern Bug River. The mineral water of Khmilnyk is healing due to the presence of an inert gas radon. It is successfully used for baths (so-called radon baths), as well as for intake [16].

Cherche is a balneological and mud resort in Ukraine. Cherche village stretches through the forest-steppe zone, near the rivers Struh and Potyk. Unique mineral resources containing sulfurous sulphated-hydrocarbonate-calcium and sulfate-calcium water bring glory to the Cherche resort. Sulfate-calcium mineral water is used for drinking and sulfurous sulphated-hydrocarbonate-calcium - for bathing [17].

The resort of Berehove is known for thermal springs, where there are wells with hot mineral water, which are iron-saturated. There are thermal sources of high mineralization in two lakes, analogues of which can be found in Kamchatka and Sakhalin, Iceland and Hungary [18].

One of the oldest resorts in Europe is in the village of Velykyi Lubin. The therapeutic hydrogen sulfide sources of it were described by the personal physician of King Stefan Batory. The main therapeutic factors are hydrogen sulfide water of the type "Matsesta" and peat mud [19].

Medobory is a unique geological and botanical place. Modern Medobory is a real treasure of medical factors. Podilski Tovtry has a beneficial regional climate forcing effect. The height of the ridge and its position create favorable microclimatic conditions for the person. Nature has given this corner a unique underground treasure - healing water. Nowadays, four natural factors are used for medical and preventive purposes: hydrogen sulfide water of the famous "Matsesti", iodine-bromine sodium chloride mineral water of the Morshyn specimen, sulphate-hydrocarbonate peat and blue clay. Procedures using peat moss and ozocerite with regenerative properties are also popular. In sanatoriums for the treatment of joints, applications of medical ozocerite and mud are practiced. The refined mountain wax is a natural source of many minerals and inorganic compounds, namely mineral oils, potassium, iron, propylene, sulfur, sodium and other useful elements. The tissues supply with the necessary components occurs under the influence of this substance application stimulating regenerative and healing processes [20].

The main positive effects of the medical ozocerite usage are pain syndrome relieving; anti-inflammatory action in the knee joints treatment; resorption of pathological changes occurred in the joint tissues; normalization of impaired blood circulation; prophylaxis of lymphostasis and toxin production.

Ukraine is rich in curative mud deposits, unexpired lichen and lake mud deposits in the Black Sea coasted area - in the Kuialnytsky and Khadzhibei estuaries in Odesa. The second most important reserves of mud are the Crimean mud lakes: Saky, Moinake (Yevpatoriia), AjiGol (the territory of Feodosia), Chorkaia lake on the Kerch peninsula, Syvash and others. Mud resorts of Odesa and Crimea are considered the oldest Ukrainian resorts. The Utliuha estuary in Kyrylivka village of the Zaporozhzhia region and the mud lakes of Berdiansk are the largest reservoirs of medicinal mud on the Azov Sea coast.

The Solotvyn salt lakes are known for mud which is rich in useful trace elements. It is proved that the water of the Solotvyn lakes is similar in composition and therapeutic properties to the Dead Sea waters. The largest of the Solotvyn Lakes is the Kunihunda Lake. It appeared in a place of flooded mine building dating back to Austrian times. People who cannot swim are able to do so in salty water because it pushes swimmers to the surface, covering the body with salt crystals. The Solotvyn lakes water effectively treats cardiovascular, nervous, musculoskeletal system and skin diseases [21].

In addition to mud estuaries and lakes of marine origin, there are a number of salt lakes of continental origin in Ukraine including lakes in Hola Prystan in the Kherson region, salt estuary in the Dnipropetrovsk region and salt lakes in Veisove, Rapne and Slipne in the Slavic resort in the Donetsk region [6].

There is a unique resort in Serhiivka in the Odesa region. This place is special because the estuary with healing mud divides the village into several parts. In particular, the main part of Serhiivka is located on the mainland. To reach the shore you should pass a "kilometer of health" - it is the distance, which stretches across the estuary to the sea. People visit Serhiivka also because of mud. Sanatoriums have been built there with the provision of a full range of therapeutic procedures for the musculoskeletal system [22].

Beaches are important recreational resource. There are many beaches in Ukraine, because a large number of sanatoriums and resort facilities are located on the coasts of the seas and on banks of the rivers and lakes. The seaside is the most popular place. The combination of quality, quantity and nature of climatic conditions, balneological and landscape resources of sea beaches, the sea and coastal waters determine its healing properties.

The detection of natural healing resources is carried out by complex medical-biological, climatological, geologi- 
cal-hydrological, resort and other research works. Medico-biological assessment of the quality and value of natural therapeutic resources, determination of their methods usage are carried out by the Ministry of Health care based on research data. According to the results of geological exploration operations, operational reserves of medicinal underground mineral waters, therapeutic mud and other minerals belonging to natural therapeutic resources are approved and introduced into the State Fund of deposits, minerals of Ukraine and provided for use in accordance with the legislation of Ukraine (Article 16 of the Law of Ukraine "On Resorts") [3].

As to the issue of the organizational and legal support of the resort business development, it is important to note that the Strategy of the tourism and resorts development until 2026 was approved by the Cabinet of Ministers of Ukraine, dated $16^{\text {th }}$ March 2017, No. 168-p. However, the aforementioned Strategy, firstly, is not performed as to its basic provisions, and, secondly, contains no specific action plans, measures, responsible persons indicated, performance time limits, and therefore has declarative nature. Thirdly, the documents of such importance, in our opinion, should be approved by the legal act in accordance with the Constitution of Ukraine.

The analysis of Art. 85 and 116 of the Constitution of Ukraine proves that the program documents constitute the economic, scientific and technical, social and cultural development of Ukraine and should be adopted by the Verkhovna Rada of Ukraine and prepared by the Cabinet of Ministers of Ukraine. Under Art. 10 of the Law of Ukraine "On State Target Programs", state programs of economic, scientific and technical, social and cultural development and environmental protection are adopted as laws following the relevant proposal of the Cabinet of Ministers of Ukraine.

\section{Conclusions}

1. Legal regulation of the natural therapeutic resources usage is ensured by environmental, land, health care and resorts legislation. The purpose of this legislation is to regulate social relations in the sphere of organization and development of resorts and sanatorium-resort treatment, detection and accounting of natural medical resources, ensuring their rational extraction, use and protection in order to create favorable conditions for treatment, medical rehabilitation, prevention of diseases and vacation for people.

2. The financial and economic crisis, which has aggravated in recent years, the events associated with the annexation of the Autonomous Republic of Crimea and anti-terrorist operations on the territory of the Donetsk and Luhansk regions had a negative impact on the sanatorium and resort structure of our state. In fact, the number of foreign tourists has diminished twice. Ukraine loses its popularity as a health-resort hospital, because the country is perceived as a crisis spot. In addition, the resort development is closely linked to the country's environmental security. Negative influence on the environment is caused by harmful emissions, land pollution by sewage and industrial waste, spontaneous building of sanatorium and resort areas, etc. The natural resources of the health-improvement lands are exposed to enormous anthropogenic impact, caused by the operation of industrial enterprises, utilities, automobile and marine transport. The current ecological situation has a very devastating effect on the mineral springs and mud deposits state. Enabling favorable environment to enhance the development of spa treatment in accordance with international standards of quality and taking into account European norms will improve the quality of life of the population and harmonious development of the society.

3. Based on the foregoing, we propose to adopt the State Program of the Social and Economic Development of Resorts and Health Tourism, which should be adopted by the Verkhovna Rada of Ukraine, prepared and performed by the Cabinet of Ministers of Ukraine in accordance with the Constitution of Ukraine as well as other legislative documents as important State activities in the public health sector.

4. Such program should include the following:

- increasing availability of resort treatment for the Ukraine population as a significant factor in preserving and restoring physiological and psychological functions, human optimal performance and social activity;

- counteracting the illegal privatization of sanatorium facilities and their illegal development;

- improving the environmental situation in Ukraine in general and within resort areas in particular;

- promoting Ukrainian health tourism in the world, increasing tourist attractiveness of Ukrainian resorts for foreign tourists as a way to uphold the efficiency of unique natural therapeutic resources exploitation in order to achieve significant social and economic effect for the state and society.

Conflicts of interest: authors have no conflict of interest to declare. Конфлікт інтересів: віАсутній.

Нааійшла Ао реАакції / Received: 05.09.2019

Після Аоопрацювання / Revised: 09.09.2019

Прийнято Ао Аруку / Accepted: 16.09.2019

Informations about authors:

Kostytsky V. V., PhD, DSc, Professor of the Theory of Law and State Department, Taras Shevchenko National University, Kyiv. Academician of the National Academy of Legal Sciences of Ukraine, President of the International Association of Medical Law, Kyiv, Ukraine.

Sydor V. D., PhD, DSc, Professor of Constitutional, Administrative and International Law Department, Kyiv Institute of Intellectual Property and Law, National University "Odesa Law Academy", Ukraine.

Kostytska I. O., PhD, Senior Researcher, Deputy Head of the Department, Institute of Legislation of the Verkhovna Rada of Ukraine (Ukrainian Parliament), Kyiv.

\section{Відомості про авторів:}

Костицький В. В., А-р юриА. наук, професор каф. теорії права та Аержави Київського національного університету імені Тараса Шевченка, Аійсний член (академік) Національної академії правових наук України, президент Міжнародної асоціації медичного права, м. Київ, Україна.

Сияор В. А., А-р юриА. наук, професор каф. конституційного, аАміністративного та міжнароАного права Київського інституту інтелектуальної власності та права, Національний університет "ОАеська юридична академія", Україна.

Костицька І. О., канА. юриА. наук, старший науковий співробітник, заст. завідувача віААілу, Інститут законодавства Верховної Ради України, м. Київ. 
Сведения об авторах:

Костицкий В. В., А-р юриА. наук, профессор каф. теории права и государства Киевского национального университета имени Тараса Шевченко, действительный член (академик) Национальной академии правовых наук Украины, президент МежАународной ассоциации меАицинского права, г. Киев Украина.

Сидор В. А., А-р юриА. наук, профессор каф. конституционного, административного и международного права Киевского института интемектуальной собственности и права, Национальный университет "ОАесская юридическая академия", Украина.

Костицкая И. А., канА. юриА. наук, старший научный сотрудник, зам. зав. отделом, Институт законодательства Верховной Рады Украины, г. Киев.

\section{References}

[1] Konstytutsiia Ukrainy: Zakon Ukrainy vid 28.06.1996 roku №254k/96VR [The Constitution of Ukraine: Law of Ukraine dated June 28, 1996 №254k/96-VR]. Retrieved from http://zakon.rada.gov.ua/laws/ show/254k/96-vr. [in Ukrainian].

[2] (1992). Osnovy zakonodavstva Ukrainy pro okhoronu zdorovia: Zakon Ukrainy vid 19.11.1992 roku №2801-XII. [Fundamentals of Ukrainian healthcare legislation: Law of Ukraine from November 19 1992 №2801-XII]. Retrieved from https://zakon.rada.gov.ua/laws/ show/2801-12. [in Ukrainian].

[3] (2000). Pro kurorty: Zakon Ukrainy vid 05.10.2000 roku №2026-III. [On resorts: Law of Ukraine from October 5, 2000 № 2026-III]. Retrieved from https://zakon.rada.gov.ua/laws/main/2026-14. [in Ukrainian].

[4] (1991). Pro okhoronu navkolyshnoho pryrodnoho seredovyshcha: Zakon Ukrainy vid 25.06.1991 roku №1264-XII. [On environmental protection: Law of Ukraine from June 25, 1991 №1264-XII]. Retrieved from https://zakon.rada.gov.ua/laws/main/1264-12?lang=uk. [in Ukrainian].

[5] Kulynych, P. F. (2008). Pravovyi rezhym zemel ozdorovchoho pryznachennia [Land legal regime of health purpose]. Justinian, 2, 15-21. [in Ukrainian]

[6] Goldenberg, N. Ja. (1996). Kurort Khmelnyk [Khmelnik resort]. Kiev: Health. [in Russian].

[7] Truskavec. Mineralnye istochniki [Truskavets. Mineral springs]. Retrieved from http://www.truskawets.com/istochniki.html. [in Russian].

[8] Skhidnytsia. Mineralni dzherela [Skidnytsya. Mineral springs]. Retrieved from http://www.shidnitca.com/index2.html. [in Ukrainian].

[9] Morshyn mineralni vody, ozokeryt [Morshin mineral water, ozokerite]. Retrieved from http://www.morshin-ua.com/mistochniki.html. [in Ukrainian].

[10] Kurort Poljana [Polyana health resort]. Retrieved from http://www. polyana-info.com/polyanao.html. [in Russian]

[11] Sanatorii Hirska Tysa - Kvasy, Zakarpattia [Girska Tysa health resort - Kvasy, Transcarpathia]. Retrieved from https://sanatorii-zakarpattia. com/ua/gornaya-tisa/. [in Ukrainian].

[12] Shajan balneologicheskij kurort [Shayan balneological health resort]. Retrieved from http://www.shayan.com.ual. [in Russian]

[13] Sanatorii Syniak - Zakarpattia [Synyak Health Resort - Transcarpathia]. Retrieved from https://sanatorii-zakarpattia.com/ua/sinyak/. [in Ukrainian].

[14] Kurort Mizhhiria [Mizhhirya health resort]. Retrieved from http://www. mijgirya.com/. [in Ukrainian].

[15] Kurort «Myrhorod» - tut zhyve zdorovia! [Myrhorod health resort health lives here!]. Retrieved from http://www.mirgorodkurort.ua/uk. [in Ukrainian].

[16] Khmilnyk-balneolohichnyi kurort [Khmilnyk balneologilcal health resort]. Retrieved from http://www.hmilnyk.com.ua/indexua.html. [in Ukrainian].

[17] DP Sanatorii «Cherche» [Public establishment "Cherche health resort»]. Retrieved from http://ukrzdrav.com/dp-sanatorij-cherche. html. [in Ukrainian].

[18] (2017). Thermal waters in Berehove review. Retrieved from https:/l destinations.com.ua/wellness/thermal-waters-in-berehove-review.

[19] Sanatorii Liubin Velykyi - Lvivska oblast vidpochynok, likuvannia v sanatorii [Velykyi Liubin sanatorium - Lviv region rest, treatment in the sanatorium]. Retrieved from https://sanatoriy-lubin.ub.ua/service/. [in Ukrainian].

[20] Sanatorii «Medobory». Fabryka zdorovia [Medobory health resort. Health factory]. Retrieved from http://www.medobory.com.ua/treatment_u.html. [in Ukrainian].

[21] Solotvyno. Retrieved from https://www.karpaty.info/en/uk/zk/tc/ solotvyno/

[22] Sergeevka - sanatorii, bazy otdyha, pansionaty. Otdyh i lechenie [Sergeevka -health resorts, recreation centers, residential facilities. Rest and treatment]. Retrieved from http://litomore.com.ua/resorts/ sergeevka. [in Russian]. 